原著 特定職域集団における死亡状況の観察

\author{
中村 健一*1, 近江 明*2, 鈴木 誠一*3, 小沼 正哉*4 \\ 栗原 忠雄*5, 田寺 守*6, 柴田 茂男*7

\section{OBSERVATIONS ON MORTALITY IN SELECTED WORKING POPULATIONS}

\author{
Kenichi Nakamura, ${ }^{* 1}$ Akira OHMI, ${ }^{* 2}$ Seiichi Suzuki, ${ }^{* 3}$ \\ Masaya Konuma, ${ }^{* 4}$ Tadao Kurihara, ${ }^{* 5}$ Mamoru TAderA*6 \\ and Shigeo SHIBATA*?
}

\begin{abstract}
Mortality among employees of selected enterprises in which excellent health care programmes are carried on, was observed to evaluate employees' health levels and to establish objectives for future health care programmes. Also, these data were compared with those for all Japanese and for Japanese employees belonging to the corresponding occupational groups.

Seventy-three enterprises which continuously participated in the mortality survey implemented by the Japan Research Organization of Industrial Health Care for the period between 1976 and 1980, were subjected to this study. The observed employees amounted to $3,502,580$ person-years. Sex and age distributions of the employees were available for 47 enterprises and the observed employees
\end{abstract} totalled 2,598,672 person-years.

The main results are as follows :

1) Mortality rate (per 100,000) is stable between 140 and 150 throughout the observed period and the average value is 145.0 . The average mortality rate for males, aged 40 to 54 , is 272.6 .

2) Malignant neoplasms were the main cause of death and account for $37-38 \%$. In second place and below are heart diseases, cerebrovascular diseases, accidents, suicide and liver cirrhosis. Malignant neoplasms, especially of the stomach, lung and pancreas, show a trend to increase, and cerebrovascular diseases and liver cirrhosis show a trend to decrease. Among heart diseases, ischemic heart disease accounts for about $40 \%$ and shows no marked fluctuation. Among cerebrovascular diseases, the relative frequency of subarachnoid hemorrhage is increasing.

3) Comparing the mortality rates for males aged $\mathbf{4 0}$ to $\mathbf{5 4}$ by industry, "Iron, steel \& nonferrous metal manufacturing" and "Electricity and gas supply" show significantly higher values, and "Finance \& insurance" and "Communications" show significantly lower values than the total.

4) The distribution of main causes of death for males, aged 40 to 54 , was compared by major

\footnotetext{
*1 高知医科大学萿生学教室

*2 商工組合中央金庫健康管理センター

*8 労働医学研究会八重洲口猃療所

*4 小沼労働衛生コンサルタント事務所

*5 国鉄中央保健管理所

*6 東京証券践康保険組合

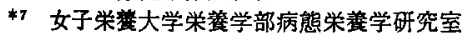
昭和58年12月15日受付

*1 Department of Environmental and Occupational Health, Kochi Medical School

*2 Health Service Centre, Sho-chukin Bank

*3 Occupational Medical Research Association

*4 Konuma Occupational Health Consultant Office

* Central Health Institute, Japanese National Railways

* Health Insurance Society of Tokyo Stockbrokerages

* ${ }^{2}$ Laboratory of Clinical Nutrition, Faculty of Nutrition, Kagawa Nutrition College Received for publication, December 15, 1983
} 
occupational groups using Proportional Mortality Ratio (PMR). A significantly high frequency of malignant neoplasms (especially of the stomach) is observed for "Professional \& technical workers, managers and officials " and that of suicide for "Craftmen, production process workers and labourers" and that of cerebrovascular diseases (especially cerebral hemorrhage) for "Protective service workers."

5) Standardized Mortality Ratio (SMR) for males, aged 20 to 54, from all causes of death, calculated on the basis of all Japanese males in 1978 is 0.57 . SMR for this population from malignant neoplasms is 0.89 . SMR for the same population from all causes of death, calculated on the basis of Japanese male employees in occupational groups corresponding to the studied population in 1975 , is 0.75 , and that from malignant neoplasms exceeds 1.00 .

Consistent with previous reports, mortality rates in this occupational population are significantly lower than those for the total population and the so-called "healthy workers effect" is demonstrated. Moreover, very low mortality rates from tuberculosis and cerebrovascular diseases suggest the effectiveness of disease control programmes which are implemented continuously and throughly in these enterprises. Efficient control programmes against malignant neoplasms remain to be established even in these well-cared populations.

\section{I. 緒言}

近年のわが国に和ける應業構造や就業形態の急激な変 化により，就業人口中雇用者の占める割合は增加の一途 をたどり，1980 年国勢調查によれば 20〜59 歳人口中の 雇用者（役員を含む）の割合は，男 $73.3 \%$ ，女 $36.6 \%$ となっている.

悪性新生物，脳血管疾患，虚血性心矤患などのいわゆ る成人病の発生に，小児期以後の生活習慣や環境条件な と゚と並んで, 職業と直接, 間接に関連する諸要因が重要 な役割を演じていることがしたいに明らかになり，青壮 年層におけるこれら疾患の予防対策実施の必要性が強調 されている.上記のように青壮年男子では職域集団に属 する者が 4 分の 3 近くに達し，しかも職場間移動の少な いわが国の特性から考古て，職域集団は成人保健対策の アプローチに好適な集団といえる.しかし，残念ながら 職域集団に指ける保健活動には事業所間に大きな格差が 存在し，その格差が従業員の健康水準にも影響している と考えられる.

1961年に発足した産業健康管理研究全国会議（略称全 産研）は，水準の高い保健活動を行っている事業所の医 師，衛生管理者などの全国的組織であるが，ここでは 1962 年以来每年 100 万人以上にのぼる参加事業所従業 員の死亡状況調查を実施している. 現職勤労者の死亡率 は，一般的には年間 1,000 人につき $1 \sim 2$ 人で，決して 高いとはいえないが，死亡は把握が確荚でその原因す明 らかにしやすいことから，大規模な職域集団について死 亡率や死因構成の動向を観察することは, その集団の健 康水準の把握, 保健対策の目標設定, さらに他の集団や 全国民との比較による保健対策効果の評価などに重要な 意義を有している.
全産研死亡調査の結果は毎年同会議で報告されてお り，1979年分を中心に筆者らがまとめた成績はすでに公

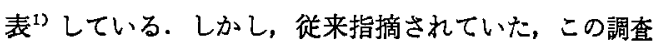
の対象事業所が年によって若干変動する，という久点を 除去して精密な観察を行う必要があると考え，1976 80 年の 5 年間継続して報告のあった事業所のみについて， 集計解析した.

わが国では最高水準の健康管理が行われていると思わ れる事業所從業員の死亡状況を，一般国民や類似職種從 事者との比皎む含めて明らかにしょ5とするのが，その 目的である。

\section{II. 研 究 方 法}

この死亡調查は, 毎年11 12月に各地区での研究集会 時等を利用して, 調查の趣旨, 記入力法などを説明した 後, 調查票を配布し前年の死亡状況や従業員数の記入を 依頼する方式で実施している．ただし，欠席した事業所 や都合により集会が開催されなかった地区では事業所に 直接調査票を郵送している.

調査内容は, 事業所の所在地, 業種, 前年のある時点 における性・5 歳年齢階級別従業員数技よび同年 1 年間 の死亡者の性別, 年龄, 職種, 死因である. 職種につい ては，生前最も長く従事していたものを，昭和50年国勢 調查用職業中分類に従って記入してもらった。

調査票は原則として郵送により回収し，疑問点につい ては照合確認のらえ, 1 死亡例につき1枚のマークカード に主要事項を転記し,カードセレクターにより集計した.

調查協力事業所数（銀行のよらに分散事栄所をるつ企 業や総合健康保険組合は，ほとんどそれらを一括して報 告しているので, 労衝安全衛生法にいう事業所とは異な る）は毎年 200 前後, 従業員数 120 130 万人であるが, 
Table 1. Number of enterprises and employees by district. (Both sexes combined.)

\begin{tabular}{|c|c|c|c|}
\hline District & $\begin{array}{l}\text { Number of } \\
\text { enterprises }\end{array}$ & $\begin{array}{l}\text { Number of employed } \\
\text { persons (Average for } \\
5 \text { years period) }\end{array}$ & $\begin{array}{l}\text { Average number of } \\
\text { employed persons } \\
\text { per enterprise }\end{array}$ \\
\hline Hokkaido & $1(1)$ & $3,605($ & 3,605 \\
\hline Tohoku & $1(1)$ & $489(\quad 489)$ & 489 \\
\hline Kanto & $25(16)$ & $394,831(268,040)$ & 15,793 \\
\hline Tokai & $16(10)$ & $129,735(103,316)$ & 8,108 \\
\hline Kinki & $12(7)$ & $54,281(39,886)$ & 4,523 \\
\hline Hokuriku & $2(0)$ & $2,701(\quad 0)$ & 1,351 \\
\hline Chugoku & $5(4)$ & $41,316(38,035)$ & 8,263 \\
\hline Shikoku & $1(0)$ & $990(\quad 0)$ & 990 \\
\hline Kyushu & $10(8)$ & $72,573(66,367)$ & 7,257 \\
\hline Total & $73(47)$ & $700,521 \quad(519,738)$ & 9,596 \\
\hline
\end{tabular}

Figures in parentheses indicate the number of enterprises and their employed persons for which sex and age distributions are available.

本研究では 1976 80 年の 5 年間連続して報告のあった 73 事業所を対象とした。 その従業員数は毎年 70 万人前

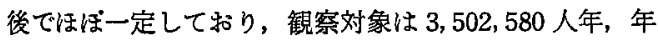
平均 700,521 人であった。これらの5ち，性・年龄階級 別分布が 5 年と子得られた事業所は 47 ，観察対象 $2,598,672$ 人・年, 年平均 519,738 人であった.

これらの事業所括よび從業員の地域別および産業別分 布は Table 1 および Table 2 に示すとおりである，地域 別では，関東が事業所数で 3 分の 1 , 従業員数で半数強 を占めて圧倒的に多い，分散事業所の場合，他地域の従 業員も本社で一括して報告されることが多いのもその一 因である. 産業別では金融・保隃, 翰送用機栈器具製造, 通信, 公安, 運輸・交通, 電気機械器具製造, 鉄鋼・ 非鉄金属製造などがおるなるのである．1事業所当り平 均従業員数は約 9,600人で，大企業中心の集団である. ただし、この 73 事業所のなかには中小企業の連合体 である総合健康保険組合が 三つ（平均徒業員数の 合計 138,717人）が含まれているので，それを除くと約 8,000 人となる。

これらの対象について，死因別死亡率の年次推移，産 業別死因別死亡率，職種別死因分布，一般国民および類 似職種就業者の死亡率との比較などの観察を行った（産 業別括よび職種別は主要なるののみ).

従業員の性・年龄階級別分布が得られた集団について は，とくに 40 54 歳男子（観察対象 749,884人・年)に

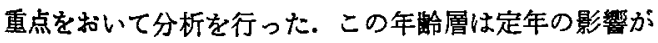
ない層のなかでは死亡率が最高であり，同じ職場に長期
間勤務している人が多いので，産業別死亡率や職種別死 因分布の格差を娭討するのに最適の集団と思われるから である.

なお，死亡者中に占める女子の割合は 7 ～8\%にすぎ ないため，女子についての分析は省略した。

産業間の死亡率の比較に際しては，全産業（性・年龄 階級別観察対象となった 47 事業所の合計）の死亡率に 基つくく期待值を用いて，カイ 2 乗法による有意差検定を 行った.

\section{III. 研 究 成 績}

1. 死因別死亡率の年次推移 (Fig. 1，2， Table 3) 5 年間の総死亡者数は 5,077 で，観察対象 3,502,580 人年に対する死亡率（以下いずれる 10 万対）は 145.0 である.これは毎年の死亡率を平均したものとはやや値 が異なるので，通算死亡率と呼ぶことにする。

年次別にみると，140 150の範囲で変動は小さい，死 因別では，悪性新生物が $37.5 \%$ を占めて第 1 位であり， 以下心疾患 $(14.7 \%)$ ，脳血管垁患 $(13.0 \%)$ ，不慮の事 故 $(9.8 \%)$ ，自殺 $(7.6 \%)$ ，肝硬変 $(4.8 \%)$ の順とな っているが，1977年だけは脳血管疾患が心疾患を抜いて 第 2 位になっている，悪性新生物は増加，脳血管疾患お よび肝硬変は減少の傾向を示している。

主要死因についてその内訳をみると，悪性新生物では 胃が約 30\%を占め, 以下肝蔵, 肺の順であり，心疾患 では虚血性心疾患が約 $40 \%$ ，脳血管疾患では脳出血が 半数強を占めている. 
Table 2. Number of enterprises and employees by industry group. (Both sexes combined.)

\begin{tabular}{|c|c|c|c|}
\hline Industry group & $\begin{array}{l}\text { Number of } \\
\text { enterprises }\end{array}$ & $\begin{array}{l}\text { Number of employed } \\
\text { persons (Average for } \\
5 \text { years period) }\end{array}$ & $\begin{array}{c}\text { Average number of } \\
\text { employed persons } \\
\text { per enterprise }\end{array}$ \\
\hline Mining & $2(2)$ & $5,473(5,473)$ & 2,737 \\
\hline Textile mill products & $4(1)$ & $3,425(998)$ & 856 \\
\hline Chemical & $6(5)$ & $18,229(15,502)$ & 3,038 \\
\hline Petroleum \& coal products & $1(-)$ & $978(-)$ & 978 \\
\hline Ceramics & $1(-)$ & $1,413(--)$ & 1,413 \\
\hline Iron, steel \& non-ferrous metals & $4(2)$ & $44,751 \quad(29,500)$ & 11,188 \\
\hline Fabricated metal products & $1(1)$ & $599(599)$ & 599 \\
\hline General machinery & $2(1)$ & $10,578(4,474)$ & 5,289 \\
\hline Electrical machinery & $4(2)$ & $48,177(22,308)$ & 12,044 \\
\hline Transportation equipment & $8(7)$ & $98,813(95,307)$ & 12,352 \\
\hline Precision machinery & $1(1)$ & $1,679(1,679)$ & 1,679 \\
\hline Other manufacturing & $2(2)$ & $1,830(1,830)$ & 915 \\
\hline Wholesale \& retail trade & $2(1)$ & $4,670(3,966)$ & 2,335 \\
\hline Finance \& insurance & $11(6)$ & $79,477(63,377)$ & 7,225 \\
\hline Transportation & $5(5)$ & $51,337(51,337)$ & 10,267 \\
\hline Communication & $6(2)$ & $63,849(47,051)$ & 10,642 \\
\hline Electricity \& gas supply & $4(4)$ & $42,489(42,489)$ & 10,622 \\
\hline Medical \& educational service & $2(1)$ & $7,162(\quad 589)$ & 3,581 \\
\hline Government (clerical) & $2(2)$ & $32,827 \quad(32,827)$ & 16,414 \\
\hline Police & $3(2)$ & $66,695(54,919)$ & 22,232 \\
\hline Other non-manufacturing & $2(1)$ & $116,070(45,513)$ & 58,035 \\
\hline Total & $73(47)$ & $700,521(519,738)$ & 9,596 \\
\hline
\end{tabular}

Figures in parentheses indicate the number of enterprises and their employed persons for which sex and age distributions are available.

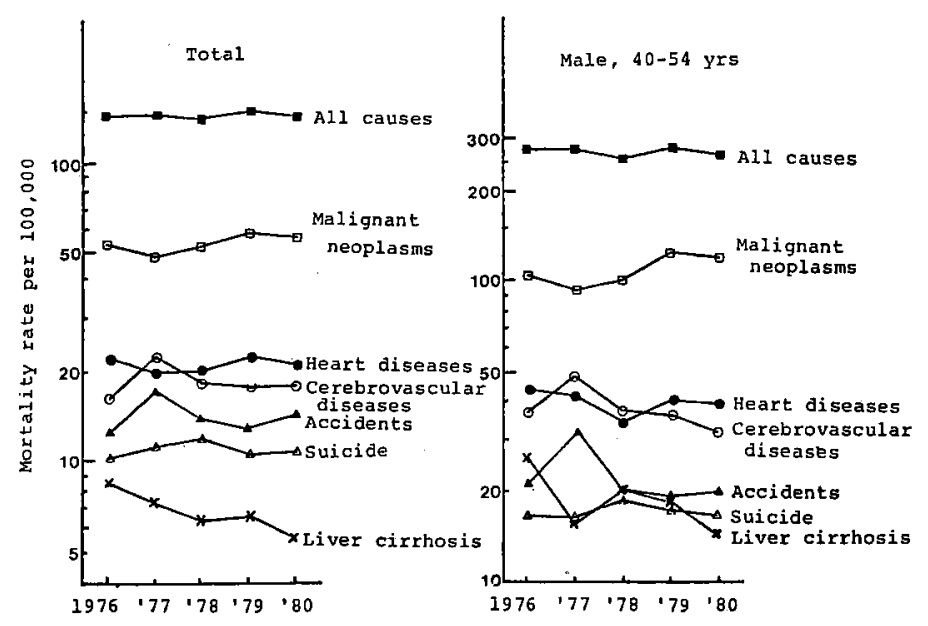

Fig. 1. Annual trend of mortality rates for main causes of death. 
Table 3. Number of deceased cases by cause of death. (Total for 5 years period. Both sexes combined.)

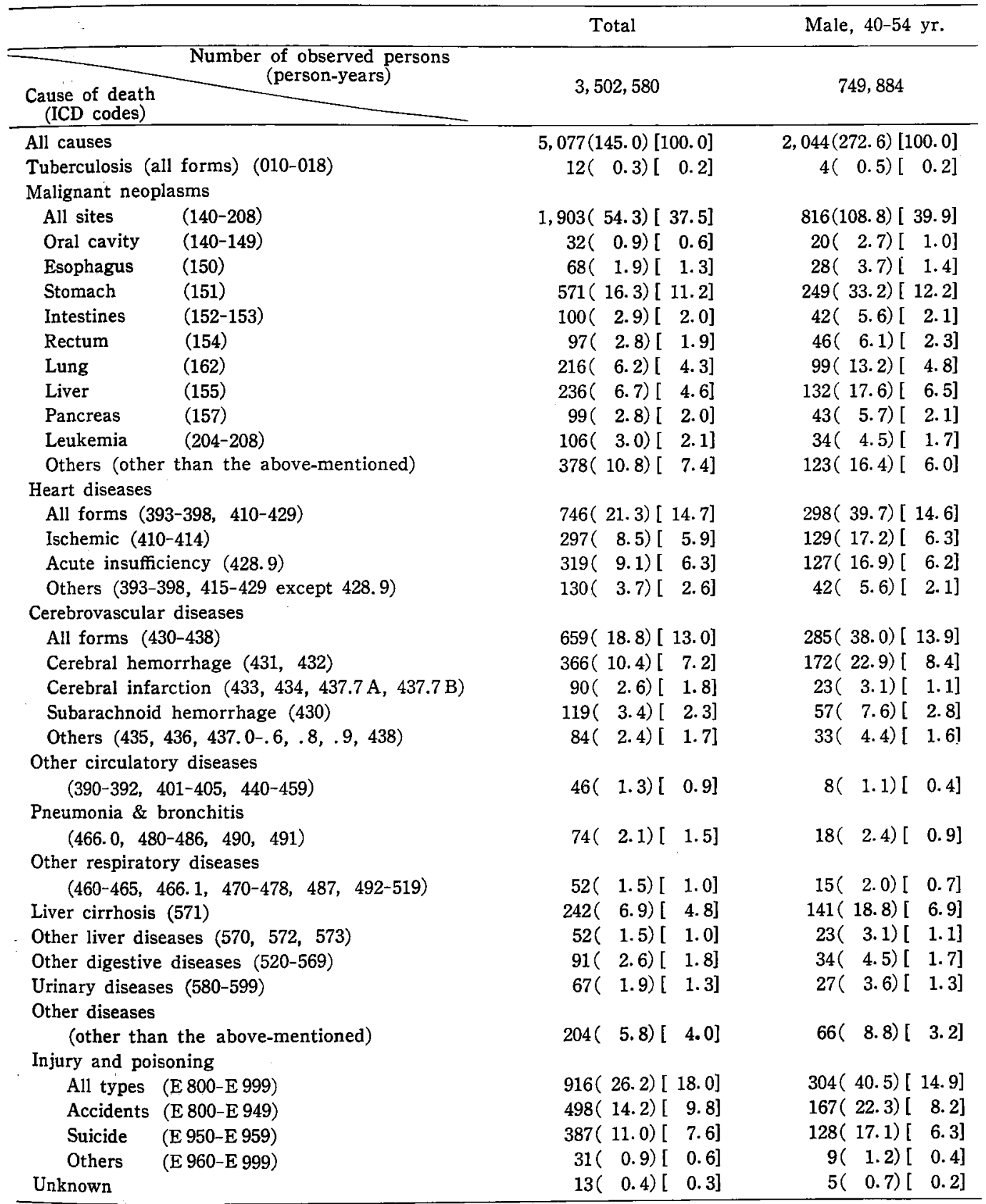

Figures in parentheses indicate mortality rate per 100,000 , and figures in brackets indicate relative frequency in percent. 


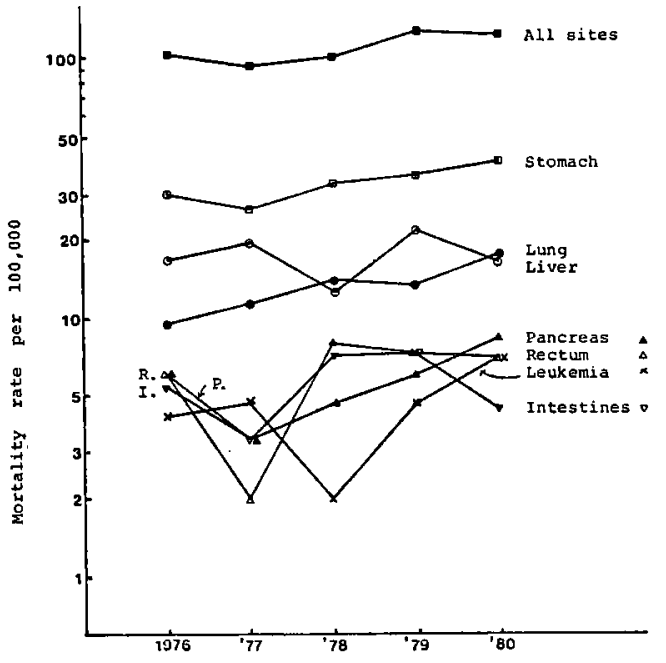

Fig.2. Annual trend of mortality rates for malignant neoplasms by site. (Male, 40-54 years of age)

40 54 歳男子（前述のように対象は 47 事業所のみ） の 5 年間の総死亡者数は 2,044 で通算死亡率は 272.6 で ある. 年次別にみると 1978 年の 258.0 が最低, 1979 年 の283.1が最高である. 死因別では悪性新生物が $39.9 \%$ を占めて第 1 位であり，以下，心疾患 $(14.6 \%)$, 脳血管 疾患 $(13.9 \%)$, 不慮の事故 $(8.2 \%)$, 肝硬変 $(6.9 \%)$, 自殺 (6.3\%) の順となっている.ただし, 年により2 位 以下の順位に多少の変動がみられる. 年次推移は全体の 場合と同で傾向を示している。

悪性新生物の部位別分布をみると，胃が約 $30 \%$ を占 め, 以下肝臓, 肺の順であるが, 胃, 肺, 膵蔵の増加傾 向が注目される.

心疾患中虚血性心疾患は $40 \%$ 強を占めているが，と くに増加の傾向はみられない.脳血管疾患中, 脳出血は 平均約 $60 \%$ を占めているが，死亡率は 1977 年の 31.9 を最高に減少し，1980 年は 16.2 で脳血管疾患中の割合 も約 $50 \%$ になった. 代わって，くる膜下出血が相対的 に増加して扣り，1980年には脳血管疾患中約 $30 \%$ を占 めている.

2. 産業別死因別死亡率 (Table 4)

性・年跉階級別従業員数が把握可能な 47 事業所の 40 〜54 歳男子について, 死因別死亡者数および死亡率の 産業間比較を行った.

A (鉱業) は不慮の事故が有意に高いＢ（化学工 業）は肝荿の悪性新生物をはじめ，悪性新生物が全般に
高い㑯向を示す，C（鉄鋼・非鉄金属製造）は，全死 因，全疾病（外因死を除いたもの），心疾患および肝硬 变が有意に高く, 肺の悪性新生物をはじめ全悪性新生物 る高い傾向を示す. D（輸送用機械器具製造）は，全䓡 病, 虚血性心疾患および肝硬変が有意低く，自殺は高 い傾向を示す，E（その他の製造業）は，媨血管疾患が 低い傾向を示す。

F（金融・保険）は，腸の悪性新生物がやや高い傾向 を示すはかは低いるのが多く，全死因，全疾病をはじめ 全脳血管疾患, 脳出血および自殺は有意に低くなってい る. G (運輸・交通) は肝硬変が有意に高い $\mathrm{H}$ (通信) は，全死因，全疾病が有意に低く，心知患も低い傾向を 示す. I (電力・ガス) は, 全死因, 全疾病, 全悪性新 生物，睟蔵の悪性新生物就よび自殺が有意に高い。しか し，心疾患，脳血管疾患などはそれほど高くない，J （非現業公務員）は，虚血性心疾患が有意に 高い点に特 致がある.K (公安) は, 全脳血管疾患, 脳出血, くも 膜下出血がいずれる高い傾向を示している.

電力・ガス，鉄鋼・非鉄金属製造，化学工業，鉱業な ぞで，全悪性新生物扰よび肺の悪性新生物死亡率が比較 的高値を示すことは注目すべき点であり，職場頊境や居 住環境との関係について詳細な検討が必要のように思わ れる。

\section{3. 職種別死因分布 (Table 5)}

死因別死亡率の職種間比較はきわめて重要であるが， 職種別従業員数の調査が困難であるため，死亡率は算出 不能である.そこで, 職種別死因分布の差から職種の死 因に及ぼす影響を検討することにした。

調查対象となった 73 事業所の 40 54 歳男子死亡者全 員（ 5 年間で 2,437 人）の死因分布を基準にして，各職 業大分類 $(\mathrm{A} \sim \mathrm{K}$ ，たたし $\mathrm{D}, \mathrm{E}, \mathrm{F}, \mathrm{J}, \mathrm{K}$ は硋当者少 数のため省略し，Aと B は統合した）ごとに死因別期 待死亡数を算出し，それで観察死亡数を除して比例死亡 比 (proportional mortality ratio, PMR) を求めた.

A \& B (尃門的・技術的職業および管理的職業従事 者）は，悪性新生物とくに胃の悪性新生物が 有意に高 く, 檤血管疾患, 肝硬変, 自殺などが低い, といら顕著 な特徵がみられる・C（事務彷事者）は虚血性心疾患中 肝硬変がやや高く，不虑の事故および自殺が低い，G （運輸・通信促事者）は肝硬变が高く，肺の悪性新生物 が低いが，いずれる有意ではない，H（技能工，生産工 程作業者および単純労働者）は自殺が有意に高く，虚血 性心疾患が低いＩ（保安職業従事者）は渞血管疾患， とくに脳出血が有意に高いほか，肝橫の悪性新生物が高 く, 肝硬変が低い傾向を示す。 


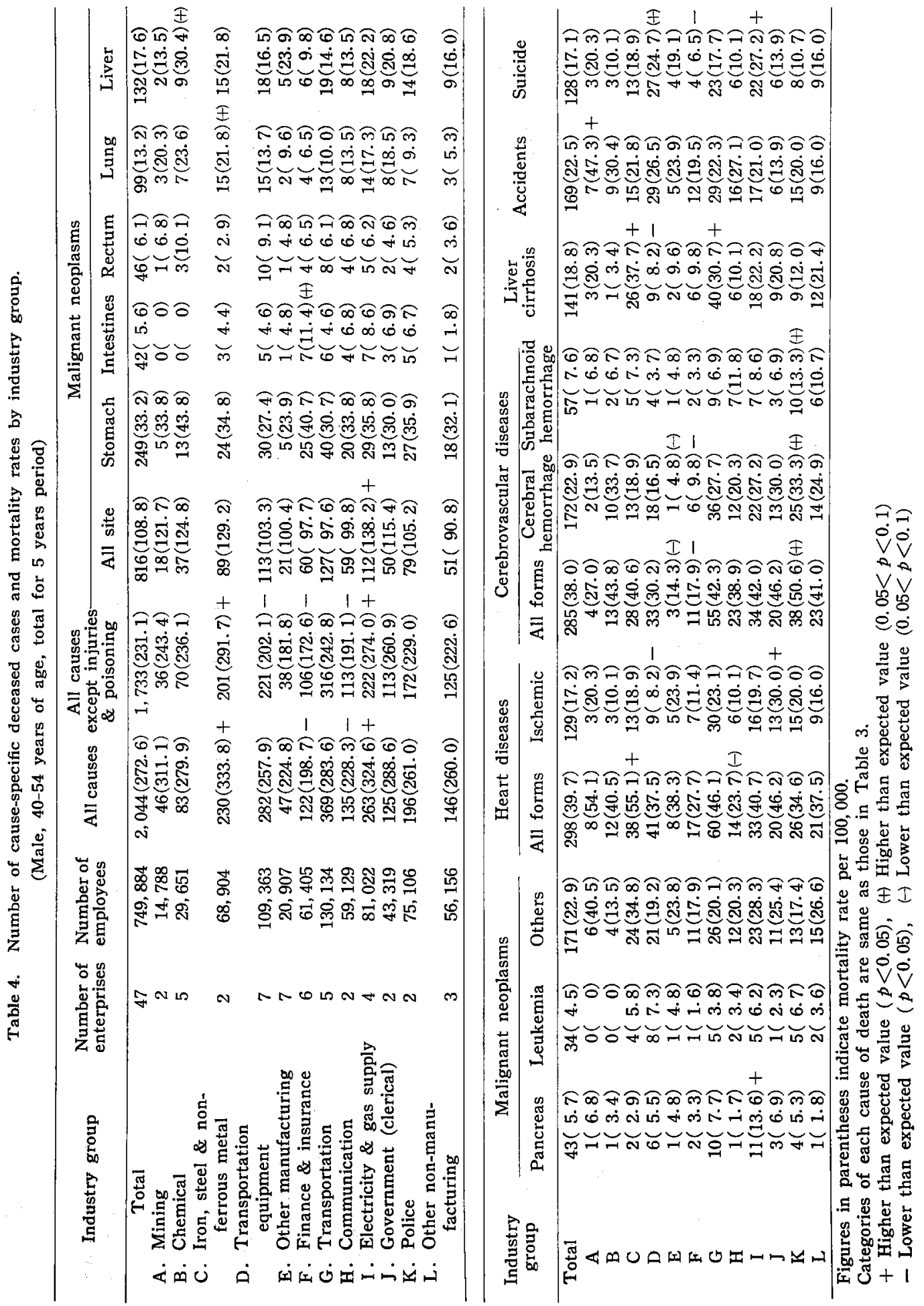




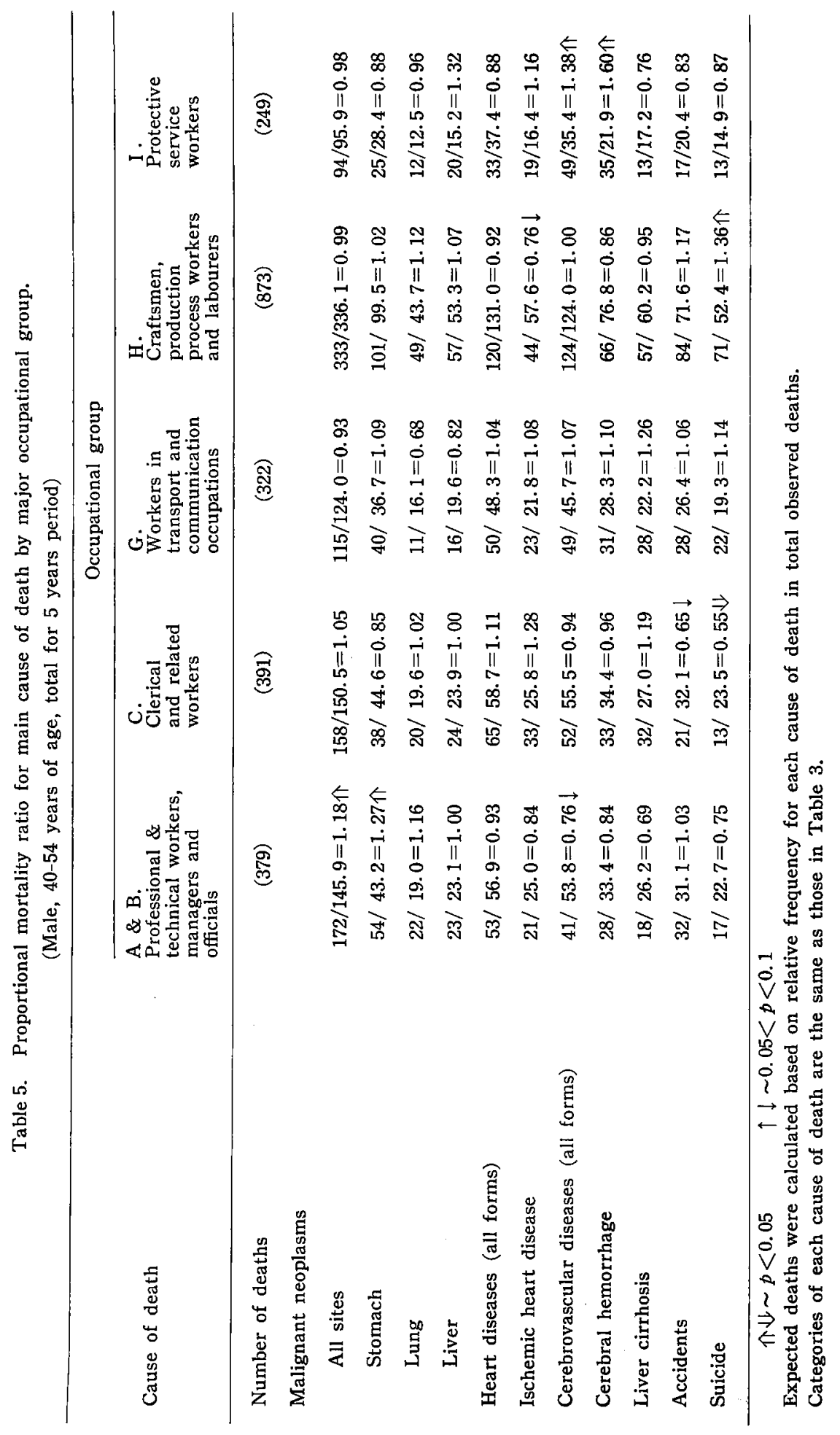


Table 6. Standardized mortality ratio (SMR) for studied population by main cause of death. (Male, 20-54 years of age, 1976-80)

\begin{tabular}{lcc}
\hline & A & B \\
\hline All causes & $0.58^{*}$ & $0.75^{*}$ \\
All causes except injuries and & & \\
poisonings & $0.62^{*}$ & - \\
Tuberculosis (all forms) & $0.05^{*}$ & $0.11^{*}$ \\
Malignant neoplasms (all sites) & $0.89^{*}$ & $1.17^{*}$ \\
Stomach & $0.77^{*}$ & 0.94 \\
Lung & 1.05 & $1.40^{*}$ \\
Liver & 0.91 & - \\
Pancreas & 0.89 & - \\
Leukemia & 0.94 & 1.04 \\
Heart diseases (all forms) & $0.76^{*}$ & 1.04 \\
Ischemic heart diseases & $0.71^{*}$ & 0.89 \\
Cerebrovascular diseases & & \\
(all forms) & $0.52^{*}$ & $0.64^{*}$ \\
Cerebral hemorrhage & $0.51^{*}$ & - \\
Pneumonia and bronchitis & $0.34^{*}$ & $0.52^{*}$ \\
Liver cirrhosis & $0.46^{*}$ & $0.74^{*}$ \\
Accidents & $0.52^{*}$ & $0.49^{*}$ \\
Suicide & $0.49^{*}$ & $0.77^{*}$ \\
\hline I Expeted & &
\end{tabular}

* Expected deaths were calculated based on age-specific mortality rates for (A) all Japanese males in 1978, and (B) Japanese males in 1975 in occupational groups corresponding to studied population.

* : Significantly higher or lower than expected value.

Categories of each cause of death are the same as those in Table 3.

これらはいずれる相対值であるから，本調查対象集団 全体の死因分布の特徵を念頭に蛇いて，解䣋する必要が ある.

4. 一般国民および対凩職種就業者の死亡率との比較 (Table 6)

性・年路階級別死亡率算出可能の 47 事業 所 従 業 員 (男, 20 54 歳) について, 1978 年の人口動態統計2) 上 り得られた全国男子の主要死因別年龄階級別死亡率を基 準にした標隼化死亡比 (SMR) を計算した。また，1975 年職業・産業別人口動態統計 ${ }^{3}$ を用いて，同様に全国就 莱者中，全産研集団にほぼ対応する 職種（大分類 A-専 門的·技術的職業從事者, B-管理的職業従事者, C-事

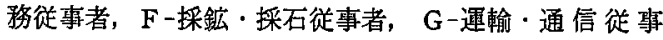
者, $\mathrm{H}$-技能工, 生産工程作業者扣よび単純労働者, I 保安職業従事者, これらを以下「対応職種」という）の 男子主要死因別年龄階級別死亡率を基準にした SMR を 計算した。

この際, 本来ならば本研究対象集団の職軼構成に心し て加重平均した死亡率を用いるべきであるが，職種構成 に関する資料は入手不可能であるため，対応する 7 職種 をプールした死し率を用いた。

全国人口を基準にした場合（表中 A)，総死亡，全病 死の SMR は 0.6 前後である. 死因別では全結核，肺 炎・気管支炎は著しく低く，脳血管疾患，肝硬変，不慮 の事故，自殺なども 0.5 前後と低いが，心疾患は 0.76 ， 覀性新生物は 0.89 とかなり接近している.とくに肺, 肝藏, 膵葴の悪性新生物や白血病は，全国水準と有意の 差は認められない。

対応職種就業者を基準にした場合（表中 B)，全体的 に SMR は上昇乙, 総死亡で 0.75 となる. 悪性新生物 は 1.17 と有意に高い值を示し, とくに肺の悪性新生物は 1.40 と非常に高い.心疾患も 1.04 と高いが，その他の 死因は有意に低くなっている.

もら一つ重要と思われるのは，5歳嘴䄲ごとに観察值 と期待值を比較すると，年龄によって両者の差がかなり 違うことである.すなわち，全国民を基準とした場合， 総死亡の観察值が期待值に対する比は，44 歳以下は 0.5 前後であるが，45〜49歳では 0.60，50 54 歳では 0.68 と上昇する.このことは，本研究集団では若年者の死亡 率が，同年代の一般国民に比へててくに低いことを示し ている。

\section{IV. 考 察}

職業生活のなかには，多くの健康に影響する因子が， 複雑な形で存在する，そのなかで最も重要なものは，い らまでもなく種々の有害化学物質や有害物理条件への暴 露, あるいは重激労働, 不適当な作業方法, 長 時 間 労 働，交代勤務などによる生理的，心理的負担である。乙 かし，これら以外にも精神労衝に伴ら精神緊張や一部の 職業に伴いやすい低所得や生活様式の歪みなどる健康に 好ましくない影響を与える因子である，近年，作業環境 の改善によって物理化学的因子による典型的職業病は著 しく減少し, 後者のような間接的因子の重要性が相対的 に高まってさたといえる。

本研究に和いては，特定の職種別母数の把捯や個々の 死亡者の職歴についての詳細な資料の入手が不可能であ ったため，個々の職業の健康影響についての分析は不可 
能であったしかし，70万人とい5大きな集団(しかむ その構成人員の移動率はきわめて小さい之思われる）に 打ける死亡状況の観察は，わが国勤労者の健康問題を考 えるらえで貴重な資料である。とくに，対象となった事 業所はかなり水準の高い健康管理活動が行われているこ とから，他の職域集団と打ける健康管理の目標となる水 準を示しているともいえよう。

勤労者の死亡状沉についての公的資料としては，厚生 省が昭和 26 年以後添ぼ 5 年ごとに発表したもの ${ }^{3 \sim 83}$ があ

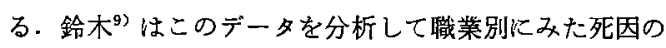
頻度を比較しており，中原ら ${ }^{10,11)}$ は同じくこのデータを 利用して産業別死亡率の統計学的解析を行っている.

鈴木によると，1970年の男子職業別訂正死亡率は「採 鉣・採石従事者」が最も高く,「農林・漁業従事者」「運 輸・通信従事者」「販売從事者」などが高率を示してお り，「管理的職業従事者」が最低となっている．また， 職業別に死因の相対的比重を比較した場合, 全結核, 糖 尿病，不喼の事故などが，職業による格差が大きい，と 述べている. しかし，実死亡者数の多い悪性新生物，心 疾患，脳血管疾患などについては，この方法では職業と の関係があまりはっきりと示されておらず，わずかに 「管理的職業従事者」および「事務従事者」に和ける徳 性新生物,「管理的職業從事者」「眅売従事者」「保安職 業従事者」および「サービス職業従事者」における肝硬 变がやや高い相対的比重を示しているにすざない．

中原らによると，1975年に利ける男子の全人口死亡率 SMR 産業別にみると, 有意们高いのは全死因では 「鉱業」と「電気・ガス・水道・熱供給業」である. 悪 性新生物ではこの 2 産業のほか,「農業」「漁業・水産養 殖業」「公務」でみられ，不慮の事故では第 1 次産業の 各産業,「建設業」「運翰通信業」でるみられ，また自殺 では「農業」でもみられている.

これらの成績と本研究の成績とをそのまを比較するの は, 対象集団の性格や規模が異なるので困難であるが, 「管理的職業従事者」で鲁性新生物の比重が 高い点や, 「鉱業」と「電気・ガス・本道・熱供給業」の死亡率が 高い点では一致している.

また，現場での観察に基づいた報告としては，出原

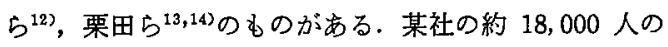
男子従業員についての 12 年間にわたる観察の結果, 若 年者では愛知県民の死亡率よりかなり低い死亡率を示す が，45 歳以上では両者間の差は急激に縮小している， と報告している.これは，本研究の成績と一致してい る.

本研究対象集団の死因分布において，悪性新生物が第
1 位を占めているのは, 最近の人口動態統計で男子 35 74 歳の各年路階級で悪性新生物が第 1 位であることか ら当然である。しかし，そのなかで胃の悪性新生物だけ はSMR が有意に低いことの理由として，本研究対象集 団のほとんどの事業所で行われている効率の高い胃集団 検診の成果か゚まずあげられよう，また，胃がんの発症は 食習慣と密接な関俰のあることが近年明らかてされつつ

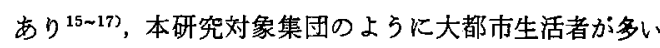
場合は，摂取食品む必然的にリスクの低い洋風のむのが 多くなると思われるので，その影響も考えられる. ただ 一つ疑問が西るのは，Fig. 2 に示したよらに全国的㑯向 とは逆に胃の悪性新生物による死亡率が近年上昇してい ることである.これが発生率の增加によるものか，発見 の遅れの増加によるものかは，今後慎重に検討する必要 がある.

肺および䏽臓の悪性新生物による死亡率の増加は，全 国的傾向の反映とみられるが，本研究対象集団のこれら の疾病に対するリスクは肺についてはその職場や住居の 架気環境, 膵藏については食生活活いて，一般国民の それより高いるのと考元らるので，今後予防対策の推 進がとくに必要である。

本研究対象集団の SMR か，悪性新生物を除くほとん どの死因で，全国民あるいは全国の対応職種就業者の水 準より有意に低いことが明らかにされたが，その理由に ついては種々のことが考兄られる。

むずFox ら selection effect'と'surviror population effect'があ る. 前者については, 本研究対象集団のよらに大部分が 大企業である場合は採用時に笡しい健康チェックが行か れているので, 当然存在する. 後者の存在るむちろん否 定できないが，終身雇用制を原則とするわが国では在職 中重病に䍜患した場合でもかなりの休職期間があるのが 通例であり，有病者の退職は欧米諸国位ど多くはないと 考えられる.職域集団の死亡率を钼察する䟢にるら一つ 注意すべき点として彼らがあげている追跡期間の問题， すなわち長期間追跡するにつれて SMR がしだに上昇 する現象であるが，本研究に和いても前述のように 45 歳以上（勤続年数の長い人々と考えてよい）でSMR が 上昇することで同様の結果を示している.

McMichael ら ${ }^{199} は$ はこのようないわゆる healthy worker effect'は，他の職種より高い死亡率が予测さ れる有害業務従事者の場合, その有害要因の影䇾を過少 評価させる危険がある，と指摘しているか，本研究の目 的が，とくに有害要因の影響解明に重点をおいたもので はないから，その点は問題にならない。ただ, 対照群 
に何をとるかは重要であり，本研究対象集団（20５4歳 男) の SMR が，全人白を基準とした場合は 0.58 ，全 就業者を基淮とした場合は 0.67 , 就業者中本集団を構成 するものとほぼ等しい職種犬゙けを基準とした場合は 0.75 とかなりの相違を示す点から, 特定職域集団の死亡水準 を評価するには，全国人口ではなくできるだけ職種構成 の等しい就業者集団を基準とすることが必要と思われ 当.

次に生活水準や生活瓖境の問題がある。

職業によって代表される社会階層が，死亡率や疾病構 造に大きな影響を及ぼすことは，古くからイギリスで報 告されている20).

現在のかが国では職種による収入や生活形態の相違 は，諸外国よりかなり小さいが，それでも本研究対象集 団俾する人々の生活水準は，一般勤労者のそれより高 いものと推定される. また，その居住地域が大都市やそ の周辺に偏しているため，公害などのマイナス面は多少 あるむのの，医療を含む生活条件に恵まれていると考兄 られる. 南関東, 東海, 山陽など, 本研究対象集団の多

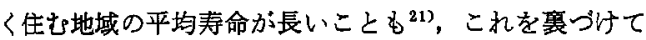
いる.

最後に,これらの事業所に括ける疾病管理対策の成果 をあげなければならない，結核，脳血管疾患（とくに脳 出血）のように，事業所に批いて早くから管理が行わ れ，その効果が現われやすい垁患による死亡率がとくに 低いことが，それを立証している。胃の悪性新生物につ いてす同様のことがいえる.

胃以外の部位の悪性新生物については，管理対策が十 分に確立していないことからここのらな成績が得られ たのも当然といえるが，今後の早期発見技術の進歩と， 開発された技術の集団管理へのすみやかな適用を期待し たい.

職域における一般疾病管理は，対象疾病の労働力損失 に及ばす影響の大きさと，管理対策の効率を適切な方法 によって評価しつつ，その戦略を考えてゆくべきであろ 5.

\section{V. 総括および結論}

レベルの高い健康管理が行われている職域集団の死亡 状況を，一般国民中対応職種従事者との比較を含めて明 らか沉することを目的として，産業健康管理研究全国会 漾の実施している死亡調查に $1976 \sim 80$ 年の 5 年間連続 して報告のあった事業所の成績を集計した.

観察対象事業所数は 73 , 従業員数は $3,502,580$ 人年 でそのらち従業員の性・年龄階級別分布が得られたの
は 47 事業所, $2,598,690$ 人年であった.

おるな結果は下記のと扣りである。

1) 死亡率は毎年 140 150（人口 10 万対）でほぽ安 定している，通算では 145.0 である.40５4 歳男子た けについてみると，通算死亡率は 272.6 となっている.

2）死因別にみると，瑟性新生物が $37 \sim 38 \%$ を占め て第 1 位であり，以下心疾患，脳血管疾患，不慮の事 故，自殺，肝硬変の順である. 悪性新生物（とくに胃， 肺，脺蔵）は增加傾向を示し，媨血管疾患と肝硬変は減 少傾向を示寸，心疾患中，虚血性心疾患は $40 \%$ 前後て ほぼ横ばいである、脳血管疾患中，くも膜下出血の相対 的比重が增加している.

3）40５4 歳男子の死亡率を産業別に比較すると， 「鉄鋼・非鉄金属製造」および「電力・ガス」では全体 より有意に高く，「金融・保険」和よび「通信」では有 意低低い。

4） 40 54 歳男子の職種別死因分布を PMR で比較 すると，「専門的・技術的職業扣よび管理的職業従事者」 では悪性新生物（とくに胃）が全体より有意に高く。 「技能工，生産工程作業者拉よび単純労働者」では自殺 が有意に高く，「保安職業従事者」では脳血管疾患（と くに脳出血）が有意に高い。

5 ） 20 54 歳男子について, 1978 年の一般国民の性. 年龄階級別死亡率を基準にして算出した SMR は 0.57 であるが，悪性新生物は 0.89 とかなり接近している。 1975 年の対応職種就業者の死亡率を基準にすると 0.75 となり，覀性新生物は 1 を超えて有意见高い值を示す が，胃の悪性新生物だけは 1 を下回っている。

以上の成績は，これまでの諸報告と同じく職域集団特 有の 'healthy worker effect' の存在を示唆している. しかし，結核，脳血管疾患などの SMR が著しく低いこ とから，本研究対象集団ではこれらの疾患に対する管理 効果が現われているように思われる。

稿を終るとあたり，調查に拹力された各事業所の健康管理担 当者括上び産業健康管理研究全国会議の各地区役員，事務局の 方々に深く感謝する。

本研究の要旨は，第 56 回日本産業衛生学会（昭和58年 4 月， 大阪）に执いて発表した。

\section{文献}

1）近江 明，鉿木誠一，小沼正哉，栗原忠雄，中村健一， 田寺 守, 枈田茂男 : 労㑬者の死亡原因に関寸る疫学的研 究, 座業医学ジャーナル, 5(4):22-29, 1982.

2) 厚生省統計情報部編：昭和 53 年人口動態統計 (上)，厚生 統計協会, 東京, 1980 . 


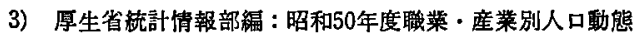

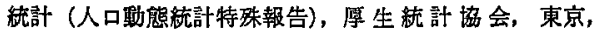
1979.

4) 厚生省統計調查部編：昭和 26 年 7 月 昭和 27 年 6 月職菜 別・産業別死亡統計，厚生統計㙝会，東京， 1955.

5）厚生省統計調查部編：昭和 29 年 眧和 31 年職業別 - 産举 別死亡毓計，厚生省統計調查部，東京， 1959.

6) 厚生省㓍計調査部編：昭和35年主要死因別訂正死亡率, 厚生省統計調查部, 東京, 1963.

7) 厚生省統計調查部稨：昭和40年主要死因別訂正死亡率, 厚生統計協会, 東京, 1969.

8）厚生省統計調查部編：昭和 45 年度職業・産業別人口動熊 梳計，厚生統計協会，東京， 1974 .

9）鈴木秤美：職業之羅病，死亡，老化，久保田重孝監修 「職業保健」, 231-272, 南江堂, 東京, 1975.

10）中原俊隆 : わが国の産業別死亡率の衛生統計学的研究, 民族衙生，47：175-186，1981.

11）中原俊隆, 馬嶋洋一, 浜野 裕, 宇都宮治, 西川溑八：

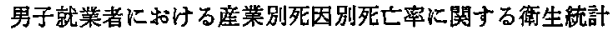
学的研究, 民族衙生, 49:67-77, 1983.

12）出原 氾，水野幸子：健康管理からみた在職死亡と停年 後死亡について, 産業医学, 13：456-457, 1971.
13）栗田英男，出原 氾：死亡状況からみた職域健康管理の 評価 (その1), 産業医学, $15: 444-445,1973$.

14）栗田英男, 出原 氾：死亡状涚からみた倳域健康管理の 評価 (その 2)，産業医学，16:230-231，1974.

15）平山 雄：癌, 悪珄新生物, 総合衛生公采衛生学 (藤原 元典, 渡辺笅一編)，981-1006，南江堂, 東京, 1978 .

16）栗田英男：胃癌の臨床疫学, 27-51, 金原出版, 東京, 1980.

17）加美山茂利：消化器がんをめぐる諸問題，公竞德生 $45: 539-545,1981$

18) Fox, A.J. and Collier, P.F.: Low mortality rates in industrial cohort studies due to selection for work and survival in the industry, Br. J. Prev. Soc. Med., 30:225-230, 1976.

19) McMichael, A.J., Haynes, S.G. and Tyroler, H.A. : Observations on the evaluation of occupational mortality data, J. Occup. Med., 17: 128$131,1975$.

20) Morris, J.N. : Uses of Epidemiology, 3rd ed., 52, Churchill Livingstone, Edinburgh, 1975.

21）厚生省統計情報部編：昭和55年地域別生命表，厚生の指 摽29巻16号（臨時增刊）, 1982.

著者への通信先 : 中村健一, $\boldsymbol{T} 781-51$ 南国市岡豊町小蓮 高知医科大学衛生学教室 Reprint requests to Department of Environmental and Occupational Health, Kochi Medical School, Kohasu, Okoh-cho, Nankoku-shi, Kochi, 781-51 Japan (K. Nakamura) 